\section{EFFECTS OF DENSITY OF SAGO/UREA FORMALDEHYDE PARTICLEBOARD TOWARDS ITS THERMAL STABILITY, MECHANICAL AND PHYSICAL PROPERTIES}

\author{
Tay Chen Chianga*, Sinin Hamdana, Mohd Shahril Osman ${ }^{b}$ \\ aDepartment of Mechnical, Faculty of Engineering, University \\ Malaysia Sarawak, 94300, Kota Samarahan, Sarawak, Malaysia \\ bSchool of Engineering and Technology, University College of \\ Technology Sarawak, 96000, Sibu, Sarawak, Malaysia
}

Article history

Received

14 April 2016

Received in revised form

23 May 2016

Accepted

15 September 2016

*Corresponding author chenchiang@hotmail.my

\section{Graphical abstract}

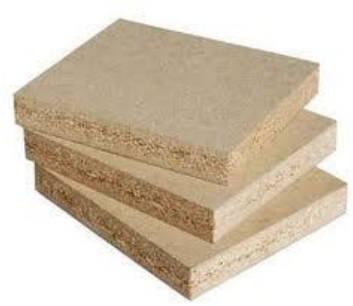

\begin{abstract}
This study examined the effect of density on the thermal stability, physical and mechanical properties of sago particleboard. Sago particles and Urea Formaldehyde (UF) were used as raw materials in the fabrication process. The fabrication and testing method were based on JIS A 5908 standard. The samples were prepared based on different desired density and went through a series of thermal stability, mechanical and physical tests. Mechanical properties of the composites were characterized by tensile, flexural, impact strength, screw test and internal bonding which had great influence on the particleboard performance. All the panels were tested for physical properties (water absorption and thickness swelling) to identify their use for indoor application. Thermal properties like thermogravimetric analysis (TGA) and differential scanning calorimetry (DSC) for the Sago/UF composites were analysed. The results showed particleboard with $800 \mathrm{~kg} / \mathrm{m}^{3}$ exhibited the optimum strength on Internal Bonding, Screw test, Bending and Flexure test. Particleboard with $700 \mathrm{~kg} / \mathrm{m}^{3}$ has better performance on Impact test. $500 \mathrm{~kg} / \mathrm{m}^{3}$ showed better curing properties with DSC. TGA showed that all the Sago/UF particleboard decompose with single-stage and were decomposed into three main steps like water absorption, volatile and char.
\end{abstract}

Keywords: Sago particleboard, Urea Formaldehyde, natural fibres, thermal stability, mechanical and physical test

\begin{abstract}
Abstrak
Kajian ini dijalankan bagi mengkaji kesan ketumpatan papan partikel sago terhadap kestabilan haba dan sifat-sifat fizikal serta mekanikal. Partikel sago dan Urea Formaldehyde (UF) digunakan sebagai bahan mentah dalam proses pembuatan papan tersebut. Kaedah pembuatan dan ujian yang digunakan adalah berdasarkan piawaian JIS A 5908. Beberapa sample telah dijalankan ujian kestabilan haba, ujian mekanikal and fizikal berdasarkan ketumpatan masing-masing. Sifat-sifat mekanikal komposit dikategorikan sebagai tegangan, lenturan, kekuata nimpak, ujian skru dan ikatan dalaman yang mempunyai pengaruh yang besar terhadap pretasi papan partikel. Di samping itu, bagi sifat fizikal (penyerapan air dan ketebalan kembangan), semua panel telah diujikaji untuk mengenalpasti kegunaan dalam ruang tertutup. Sifat haba seperti Analisis Thermogravimetrik (TGA) dan Differential Scanning Calorimetry (DSC) bagi komposit Sago/UF telah dianalisis. Papan partikel dengan ketumpatan $800 \mathrm{~kg} / \mathrm{m}^{3}$ menunjukkan kekuatan optimum dari segi ikatan dalaman, ujian skru dan ujian lenturan. Papan partikel berketumpatan $700 \mathrm{~kg} / \mathrm{m}^{3}$ mempunyai prestasi paling bagus dalam ujian impak. Papan partikel berketumpatan $500 \mathrm{~kg} / \mathrm{m}^{3}$ pula menunjukkan sifat kestabilan yang lebih baik pada DSC. TGA menunjukkan kesemua papan partikel Sago/UF mengalami
\end{abstract}

